\title{
I. Observations on the property ascribed to oil, of calming the waves of the sea
}

\section{I.F.W. Otto}

To cite this article: I.F.W. Otto (1799) I. Observations on the property ascribed to oil, of calming the waves of the sea, Philosophical Magazine Series 1, 4:15, 225-233, DOI: $10.1080 / 14786449908677063$

To link to this article: http://dx.doi.org/10.1080/14786449908677063

曲 Published online: 18 May 2009.

Submit your article to this journal

Џ Article views: 2

Q View related articles $\square$ 


\title{
THE
}

\section{PHILOSOPHICAL MAGAZINE.}

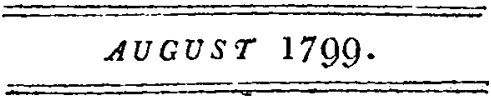

1. Obfervations on the Property afcribed to Oil, of calming the Waves of the Sea. By I. F. W. Oтто*.

\begin{abstract}
A were means capable of calming the waves of the reftlefs ocean, and of rendering its furface tranquil and even. Ariftotle fays, that every body thrown into the fea when agitated, fuch as anchors, \&c. tends to leffen the waves; becaufe a kind of eddy is thereby created, which exerts itfelf in a direction contrary to their movement, and confequently weakens them. Plutarch $\uparrow$ and Pliny $\$$ aferibe this power to oil; as they affert that it poffeffes a property by which it reftrains the reftlefs movement of water, renders its furface even, and thereby caufes the rays of the fun, which are refracted through the waves in different directions, to pafs to the bottom free and uninterrupted. What the ancients have faid on this fubject is exceedingly vague and obfcure. It

* From Von Zach's Geographifcbe Eplemeriden, Vol. II. Part 6.

+ Quart. Nat.

₹ Ea natura eft olei, ut lucem adferat et quo non aliud elementum eft implacabilius. Hif. Nal. Lib. ii. c. 103.

Vor. IV.

Q does
\end{abstract}


docs not appear clearly from their information, whether the divers, to whofe teftimony they refer, made their obfervations at the furface of the water, or at any depth. Befides, we are not able to afcertain whether they looked tbrough the oil as through a window, or as through a magnifying glafs : for if a drop of limpid oil be lct fall upon water, it will form a very fimple kind of microfcope, and marnify objects placed at a convenient depth below the water. Plutarch feems to believe, that the oil fpouted from the mouth of the diver formed, in afcending, a kind of canal, which facilitated the paffage of the light through the water*.

Of this property of oil, apparently fo wonderful, many teftimonies were afterwards produced; and it was even confecrated by fuperfition for this purpofe. Thus we are told, among the miracles of St. Cuthbert, that he gave a prieft, for a fea voyage, fome confecrated oil, by which he was enabled to allay the fury of the waves during a dreadful ftorm. Erafmus was acquainted with this property 1 ; and at prefent it is not unknown among feamen, particularly in Holland.

Not many years ago, but before the celebrated Franklin communicated to the public his obfervations on this fubject, ihe following article appeared in the Annual Regifier:"At the late fire in Thames-ftreet it was obferved that the oil, which, to prevent the farther fpreading of the fire, had been thrown into the river, vifibly calmed the violent agitation of the water. This property of oil," fays another paragiaph, "appcars to have been long known. It is ordercd, by an old marine law, that when goods, during a ftorm, mut be thrown overboard, if any part of the lading confifts of oil, it thall be the firft article thrown into the fea." In modern times we have a number of experiments which feem to leave no doubt refpecting this circumftance. I thall

* Canifius Leet. Ant. Vol. II. p. 8. ed. Bafn.

+ His words are: Nonnulli procumbentes in fabulas adorabant mare, quicquid erat olei effundentes in undas. Colloq. e recenf. P. Rabi. Ulm. $3747-8$, p. 262. 
here give an account of the mot Rriking of them, without any fear of being thought too rircumftantial, as experiments of this kind thould all be decifive.

The inhabitants of the Bermudas employ oil in their fineries, in order to render the water of the fea clear and tranfparent; and the Portuguefe failors, when they find the waves too violent on their entering the Tagus, pour a few flarks of oil into the water, by which means it is rendered calm, and their entrance becomes eafy. The divers in the Mediterranean, when they labour under water, and when the fun-beams are prevented from penetrating to them by fmall waves, are accuftomed to fpurt a little oil from their mouths. One Gilfred Lawfon, who refided feveral years at Gibraltar, relates, that the feamen of that place were accuftomed to pour a little oil into the fea, in order that they might thercby be enabled to diftinguifh the oyfters at the bottom; and that the fame practice was followed on the whole Spanith coaft. The fame thing is done on the coaft of Provence, and alfo by the irhabitants of the Hebrides. The Ragufans, with the like view, are accuftoned to fprinkle oil over the water with a brufn; and they give to the drops, under which the water becomes tranfparent, the name of windows. Tys Tiremann, a Dutch marincr, made an experiment of this kind during a ftorm, after he had !oft his rudder and fome of his fails, and, with fix half arkers of oil, calmed the fury of the waves. A lieutenant of the name of May obferved in 1735 , during a ftorm, that the fea was calm and fmooth around two hips laden with calks of oil, fome of which were leaky; and an experienced feaman, named Bewerwyk, recommends, for fecuring boats which right be fent to the affiftance of fhips in diftrefs, to throw into the fea, oil and other fat fubftances, and even beer. In a defcription of the fhipwreck of a veffel called the Anna Cornelia, this property of oil is alfo celebrated; and fome experiments made at Portfnouth, in the time of a ftorm, were attended with the beft fuccefs. In the year 1736 Detouches de la Frenaye 
faw an old failor, by this method, fave a Mip which was on the point of foundering. One Day was indebted for his own fafety, and that of his hip, to half a ton of oil. Linnæus* learned from Gronovius, that the Dutch captains who frequented Greenland, and who were reproached with concealing this property of oil, always carried fome canks of it with them when they went to the whale-fillery. The fifhermen of the Texel carry oil with them for the like purpofe. There is an inftance of a herring-bufs being faved by pouring out oil ; while another, at the diftance of two or three hundred fathoms, went to the bottom. Not only oil, under which is to be underftood fat oil, fuch as olive oil, oil of rape-feed, and linfeed oil, may be enployed for this purpofe; but alfo fat animal fluids, fuch as train-oil, \&c. Ethereal oils do not poffefs the fame property: a thip, for example, laden with oil of turpentine, which fhould employ it with the like view, would certainly fail in its end. This oil, however, diffufes itfelf very fpeedily over the furface of the water ; but the covering it forms is fo thin that it is feparated by the fmalleft external force:

At Yarmouth the failors are unanimoully of opinion, that fat fubfances thrown into the fea prevent the agitation of the waves. Pennant + mentions an obfervation made refpecting feals by the fifliermen in Scotland. When thefe animals eat any fat fifh, the fea in their neighbourhood is uncommonly ftill; a circumftance which induces them to fearch for them in fuch places. Sir John Pringle learned in Scotland, that the fifhermen could difcover at a great diftance places much frequented by herrings, as the fea, by the oily fatnefs which thefe finh cmit, has no apparent movement. It is oblerved at Rhode Inand, that the water in the harbour of Newport is always calm and ftill as long as the Greenland thips remain there at anchor. The caufe of this is afcribed

\footnotetext{
* Reife dursh Weftgothland, p. 304.

$\uparrow$ Britilh Zoology, Yol. IV.
} 
to the fea-nettle, a kind of vegetable fea-worms from oily fubitances, which are thrown together in the hold of the fips, and the oil that oozes through between the ftaves of the calks, which, of courfe, is pumped out with the bilge water. Seamen have allo obferved, that the motion of a fhip, the bottom of which has been newly payed, occafions much lefs agitation in the water than that of another which has not been daubed over with tar for a long time. Such inAtances, of which feveral more equally decifive might be produced, are fufficient to authorife this ufe of oil, in oppofition to thofe who pretend that it can be employed only in ponds and other pieces of water of fmall circumference, where, by diffufing itfelf over a mafs of water not much fwelled up, it can eafily produce a tranquil furface.

Thefe facts feem to have been unknown to Dr. Franklin until he had an opportunity of making fimilar obfervations himfelf. On his paffage from England to America fome perfon told him that he had thrown into a lake a veffel containing oil in which flies had been drowned; that the flies, which were apparently dead, began in an infant to move, and went round with a circular motion on the furface of the water. Di. Franklin afcribed this movement to a repulfive power maintained by the oil, which gradually iflued from the fpongy bodies of the flies. In the year 1757 , being at fea in the middle of a fleet confifting of ninety hips deftined for Louifburg, he obferved that the movement of the water was in one part of the fleet calm and uniform, while the water between the other fhips was thrown into great agitation by the wind. As he could not at that time difcover the caufe of this phenomenon, he alked the captain of one of the thips, who replied, that the cook had, no doubt, thrown out the greafy water, which muft have rendered the fides of the thip oily.

Franklin now paid more particular attention to this circumftance; and as he found that a drop of oil diffufed itfelf 
fpeedily over a large fpace of water, fo that it formed a thin covering to it, which reflecter prifinatic colours, he refolved to make fome farther experiments; and though they did not all fucced according to his wilh, he declared himfelf convinced of the truth of the phenomenon.

One of thefe experiments I muft here mention; for, though it does not appear very favourable to his ideas refpecting the efficacy of oil in calming the waves, it at any rate fhews that oil has a great influence on the motion of water. He difcovercd that oil excites on the water a kind of waves, under circumftances when neither water alone nor oil could produce the like. He fufpended a glafs half filled with water, and having made it to fwing backwards and forwards, after the manner of a pendulum, the water remained at perfect reft. The cafe was the fame when the glafs was half filled with oil; but as foon as he had poured oil upon the water, and continued the fivinging of the glafs, the furface of the vibrating oil remained fmooth and cyen, while the water below it was thrown into a regular agitation like that of the billows of the fea.

Franklin confiders this phenomenon, which I have confirmed by experiments, to have in it fomething fingular, and difficult to be explained. 'The caufe of it, however, may perhaps lie in the difference of the fpecific gravities of thefe two fluids, by which they are furceptible of the impulfe to movement in different degrees; and by the effort which the oil makes, on account of its lightnefs, to occupy the upper place on the furface, the water is violently agitated.

When a drop of oil is pourcd upon water in a ftate of reft, as for example in a bafon, a fine vapour immediately arifes and covers the furface of the water. It emits colourcd rays, and difperies fmall bits of paper thrown upon the fpreading drops. When the fpace on which the drop falls is fmall, it does not fpread itfelf; but feems, as it were, to be attracted towards its centre. When a bit of paper, twifted together 
in a conical form, and foaked in oil, is thrown into water, the fluid which iffues from it caufes it to turn round with a rotary motion on its centre.

In an experiment which Franklin made on a fmall lake, the furface of which was raifed into large waves by the wind, the oil fpread itfelf with great velocity, but it did not moderate the waves. The reafon of this was, that he poured out the oil at the leeward lide of the lake. He therefore went to the windward fide, where the waves originated; and there a finall quantity of oil produced, in the fpace of feveral fquare rods, a calm, which gradually extended farther until it reached the other end of the lake; and this whole part of it, for the extent of half an acre, foon became as fmooth as ice.

Of the various explanations given of this phenomenon, the following appears to be the moft natural, if not altogether fatisfactory:-The air and water have an affinity for each other, and they unite in a mechanical and chemical manner when they come in contact. It is well known that air always exifts in water; that the latter can be frecd from it under the receiver of an air-pump; and that, when the water is again expofed to the air, it abforbs a like quantity of it. When a mafs of air pretres, therefore, on the furface of a body of water, it combines itfelf in part with it, and forces it along with it. Now, if oil be poured upon water, the particles of the former attract each other with too great force to admit of their uniting with the water or the air. By the covering which the oil forms on the furface of the water, the latter is prevented from coming into contact with the air; and the wind is conveyed over its furface, without being able to force its way into it, and to raife it into waves.

The fpreading of oil in water is afcribed by Dr. Franklin to a repulfive power which they both exercife againft each other; but it is very evident that this explanation is far from being fatisfactory. Even if fuch a power actually exifted, and if the particles of the oil exercifed a repulfive power 
againft the water, and an attractive power among themfelves, they would be prevented from fpreading, in an uniform manner, over the furface of the water: they would rather form infulated globules; and, as they touch the water, would equally recede, and proceed to wards the bank or any other folid body. Oil, thercfore, as it is lighter than water, mutt float on its furface when poured upon it, and, according to the laws of hydroftatics, endeavour to extend itfelf in a lateral dircetion; and on account of the ftrong adhefion of its particles, muft form an extraordinary fine and continued fratum on the furface of the water. This diffufion, however, fuppofes that the furface of the water is horizontal: it therefore feems to follow, that the whole power of the oil confifts in preventing the formation of new waves in the places on which it has been poured; but that it cannot be in a condition to difperfe thofe which have been already formed. The billowy agitation of water fuppofes that fome part of its furface has been previounly raifed. Bodies which float upon it oppofe this rifing by their gravity, confequently the billowy movement, and in part deftroy it.

It appears therefore, to fome philofophers, that this celebrated property of oil does not confift fo much in its fluidity and toughnefs, as in its being a lighter body than water. From this it would follow, that all bodies lighter than water, and at the fame time more diftended, fuch as drops or maffes formed by oil, mult produce the fame effect, but in a higher degree. Achard recommends for this purpofe clofe leathern veffels, through which the water cannot penetrate; or, what would be fill better, tin-plate boxes of from fix to eight fect content in the bafe and two feet in height, which muft be flled with air, but rendered impenetrable to water. Ships, he thinks, without much increafing their lading, might always carry with them fome dozens of thefe veffels or boxes, to be thrown overboard, faftened to the thip with ropes, in cafe the agitation of the water fhould threaten danger. Achard made experiments, on a fmall fcale, with tin-plate boxes of 
this kind, which were attended with the withed-for fuccefs as when he employed oil: we know alfo, from the information of Scheldenung, that the whirlpool of the Maelftrom has been moderated by throwing pieces of wood into it.

To form a decifive opinion refpecting the utility of thete means, it would be neceffary to make experiments upon a large fcale. At prefent oil appears to me to deferve the preference, as it produces the effect, not only by its being a righter body, but allo by its fuidity and toughners : befides, it pofiefles this advantage, that a fmall quantity of it is fuffcient to fpread over a confiderable furface of water.

It has been objected againt this ufe of oil, that the calmnefs produced by it has been obferved to be only of thort duration, and that the fea afterwards redoubles its fury: allo, that a veffel which follows a fhip failing through water calmed by the above means, is expofed to fo much greater danger; but of this circumftance no teftimony of fufficient anthority has been alduced *.

II. Communication from Dr. Mitchile, of New-York, bewing the Utility of confluating the Houfes and pasing the Streets of Cities with calcareous in preference to fili, cecus and argillaceous Materials.

SIR,

New-York, June 6th, I799.

I

F you think the inclofed letter of any importance, I with you would infert it in the Philofophical Magazine. It is fo

* Tranfadions of the Suciery of Manchefter, Vol. 1I. Achard's Sammlung pibylkalifober und cbemijiber Abbandiungen, Vol. I. Bcrlin,

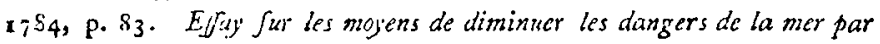
raffufon de libuile, din gondron, ou de quelque autre matiere fictante, par M. de Helyveld, Amft. 1776. Letters and Papers on Philofophical Subjects, by Franklin, p. 438. Meifter de celebratis olei aque fuperfufi effectibus opticis et mecbanicis, 1778 . - The laft work treats more on the teftimony of the Ancients, than on the experiments that bave been made. 